九州大学学術情報リポジトリ

Kyushu University Institutional Repository

\title{
Advances in nanofluids as advanced coolants for Proton Exchange Membrane (PEM) fuel cells
}

Wan Ahmad Najmi bin Wan Mohamed

Mechanical Engineering Universiti Teknologi MARA (UiTM) : Associate Professor

https://doi.org/10.5109/4102454

出版情報: Proceedings of International Exchange and Innovation Conference on Engineering \& Sciences (IEICES). 6, pp.19-20, 2020-10-22. Interdisciplinary Graduate School of Engineering Sciences, Kyushu University

バージョン :

権利関係 : 


\section{Keynote Speaker}

\section{Wan Ahmad Najmi bin Wan Mohamed \\ Associate Professor, Mechanical Engineering Universiti Teknologi MARA (UiTM), Malaysia Email:wanajmi@uitm.edu.my}

\section{Short Biography}

Wan Ahmad Najmi bin Wan Mohamed is an Associate Professor in the field of Mechanical Engineering at Universiti Teknologi MARA (UiTM) Malaysia, with teaching experience in the subjects of Thermodynamics, Heat Transfer and Renewable Energy. His specific area of research interest is in hydrogen fuel cells, nanofluids, waste heat recovery and green hydrogen systems. He has published 80 scientific papers on numerous topics, with recent publications focusing on nanofluids coolants for fuel cells and low-grade waste heat recovery using thermoelectric generators. Preparing Malaysia for the incoming hydrogen economy is one of his current agenda, specifically in providing the engineering expertise for green hydrogen production. Apart from talks on research, he is also actively invited to give talks on writing scientific publications for high impact journals. 


\title{
Advances in nanofluids as advanced coolants for Proton Exchange Membrane (PEM) fuel cells
}

\begin{abstract}
Hydrogen fuel cells convert the chemical energy in a hydrogen-based fuel directly into electrical energy through electrochemical reactions that releases heat as a by-product. Thermal management is an essential component for efficient fuel cell operation and durability. Excessive fuel cell stack temperatures cause severe imbalance to the ionic transport phenomena across the polymer membrane electrolyte and limiting the achievable current output of the stack. Fuel cell systems with large power outputs applies conventional water cooling as a thermal management method. The next generation of fuel cell stacks needs to have a more compact architecture to meet the diverse demands in practical applications. Research on nanofluids coolants for PEM fuel cell cooling is a new approach specifically for enhancing the heat transfer rates between the stack and the coolant that would lead to the reduction on the number of required cooling plates within the stack. There are diverse options for the types of nanofluids that can be applied, but coolants for PEM fuel cells needs to flow in mini-sized cooling channels and operate in an electrically conductive environment where free electrons are continuously being generated and transported from the anode to the cathode terminals of the fuel cell stack. Cooling fluids with high electrical conductivity easily attracts these free electrons to move towards the fluid stream resulting in lower yields of net stack electrical power. The main challenge is to engineer nanofluids with high thermal conductivity but low electrical conductivity (less than $5 \mu \mathrm{S}_{\mathrm{cm}}{ }^{-1}$ at $20^{\circ} \mathrm{C}$ ) and an acceptable penalty in viscosity increase. The first phase of our study in this area used very low concentrations of $\mathrm{Al}_{2} \mathrm{O}_{3}$ and $\mathrm{SiO}_{2}$ nanoparticles bonded with deionized water as well as water-ethylene glycol base fluids. Alumina Oxide nanofluids have shown promising results in enhancing the stack cooling rate (up to $180 \%$ increase) with negligible losses to the electrical power generated by the stack compared to $\mathrm{SiO}_{2}$ nanofluids. Earlier results indicate that greater voltage loss occur when the base fluid is deionized water (up to $15 \%$ reduction) compared to using water-ethylene glycol base fluid (less than 1\% reduction). Other nanofluids blends that has been studied is $\mathrm{ZnO}$ in waterethylene glycol that also shows good results for both heat transfer and power loss. Our current second phase explores the use of hybrid nanofluids to obtain a greater balance to the thermo-electrical-hydraulic coolant characteristic. Analysis on the property enhancement ratio of $\mathrm{Al}_{2} \mathrm{O}_{3}-\mathrm{SiO}_{2}$ hybrid at 10:90 ratios gives the most promising performance compared to other ratios in deionized water. Nanofluids are proven to significantly enhance the stack cooling rates that would allow a more compact future generations of stack architecture to be developed. However, the practical use of nanofluids as an advanced coolant for PEM fuel cells must still overcome several engineering challenges especially in inhibiting the increase of electrical conductivity to totally avoid the possibility of stack power losses.
\end{abstract}

